\title{
Trial-to-trial tracking of excitatory and inhibitory synaptic conductance using Gaussian-mixture Kalman filtering
}

\author{
Milad Lankarany ${ }^{1 *}$, Wei-Ping Zhu', MNS Swamy ${ }^{1}$, Taro Toyoizumi² \\ From Twenty Second Annual Computational Neuroscience Meeting: CNS*2013 \\ Paris, France. 13-18 July 2013
}

Interaction of the excitatory and inhibitory synaptic inputs constructs the shape of the receptive fields and can elucidate the synaptic mechanism underlying the functional activities of neurons. Estimating trial-to-trial excitatory and inhibitory synaptic conductance from noisy observation of membrane potential or input current can reveal drivers of neurons and play an important role in our understanding of information processing in neuronal circuits. Although recent studies introduced statistical methods that estimate trial-to-trial variation of synaptic conductance $[1,2]$, most previous works use the well- known least square (LS) method to estimate the excitatory and inhibitory synaptic conductance from the trial-mean of recorded traces of membrane potential or input current [3-5]. We first analytically show that the LS method is not only incompetent to capture trial-to-trial variation of synaptic conductance but also provide biased estimation of synaptic conductance and excitatory/inhibitory covariance if fluctuation of synaptic conductance and membrane potential is correlated. Next, we propose a novel method based on Gaussian mixture Kalman filtering (GMKF) that not only overcomes the aforementioned

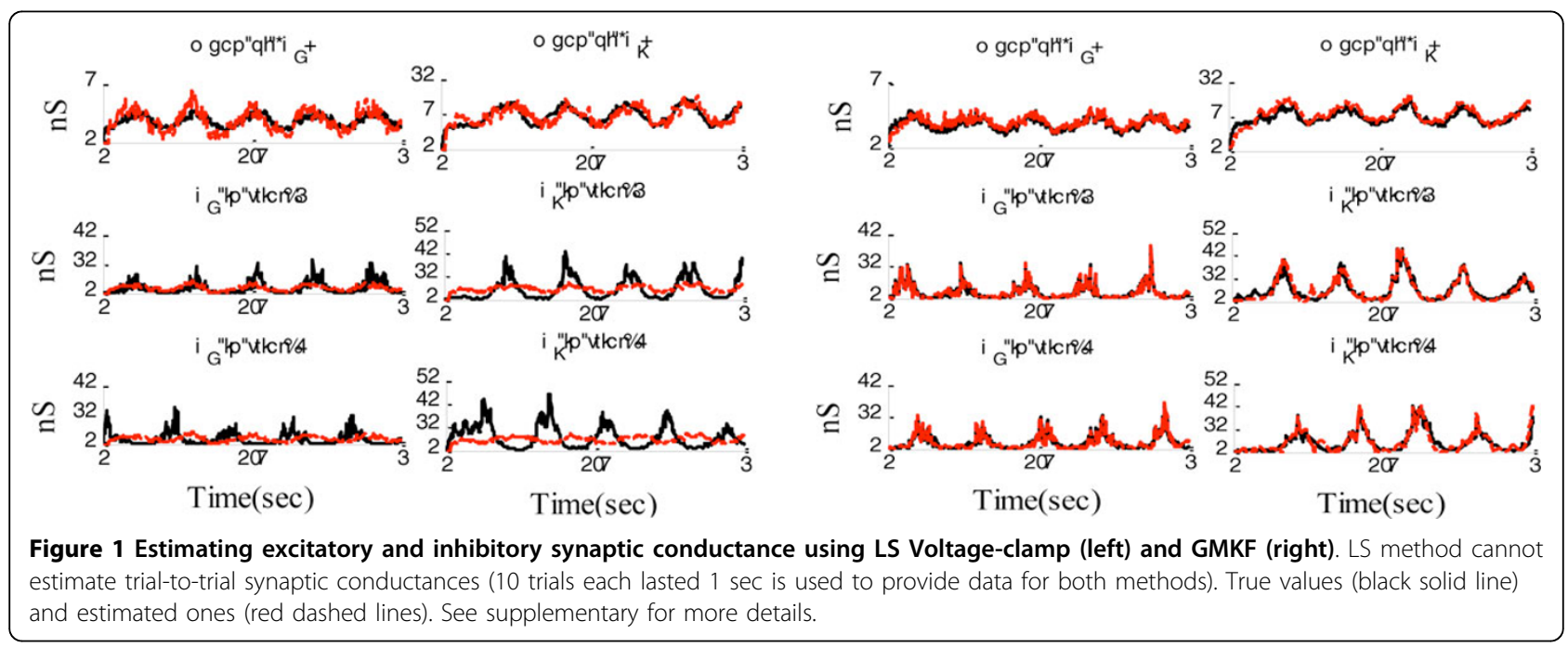

\footnotetext{
* Correspondence: m_lanka@encs.concordia.ca

'Department of Electrical and Computer Engineering, Concordia University,

Montreal, QC, Canada

Full list of author information is available at the end of the article
}

\section{(Ciomed Central}

(C) 2013 Lankarany et al; licensee BioMed Central Ltd. This is an Open Access article distributed under the terms of the Creative Commons Attribution License (http://creativecommons.org/licenses/by/2.0), which permits unrestricted use, distribution, and reproduction in any medium, provided the original work is properly cited. 
limitations of the LS method but also gives the opportunity of trial-to-trial estimation of the excitatory and inhibitory synaptic conductance. We show that our proposal requires fewer assumptions than the recent proposals $[1,2]$ that also provide trial-to-trial estimation of synaptic conductance. In particular, the proposed technique outperforms [1] by providing the ability of estimating an unknown synaptic distribution using Gaussian mixture model (GMM). We believe that our findings have a significant influence on our understanding of the balance of excitatory and inhibitory synaptic input and the underlying cortical circuitry.

\section{Author details}

${ }^{1}$ Department of Electrical and Computer Engineering, Concordia University, Montreal, QC, Canada. ${ }^{2}$ RIKEN Brain Science Institute, Tokyo, Japan.

Published: 8 July 2013

\section{References}

1. Paninski L, Vidne M, DePasquale B, Ferreira DG: Inferring synaptic inputs given a noisy voltage trace via sequential Monte Carlo methods. J Comput Neurosci 2012, 33:1-19.

2. Kobayashi R, Shinomoto S, Lansky P: Estimation of time-dependent input from neuronal membrane potential. Neural Comput 2011, 23:3070-3093.

3. Wehr M, Zador AM: Balanced inhibition underlies tuning and sharpens spike timing in auditory cortex. Nature 2003, 426:442-446.

4. Priebe NJ, Ferster D: Direction selectivity of excitation and inhibition in simple cells of the cat primary visual cortex. Neuron 2005, 45:133-145.

5. Murphy GJ, Rieke F: Network variability limits stimulus-evoked spike timing precision in retinal ganglion cells. Neuron 2006, 52:511-524.

doi:10.1186/1471-2202-14-S1-O2

Cite this article as: Lankarany et al:: Trial-to-trial tracking of excitatory and inhibitory synaptic conductance using Gaussian-mixture Kalman filtering. BMC Neuroscience 2013 14(Suppl 1):O2.

\section{Submit your next manuscript to BioMed Central} and take full advantage of:

- Convenient online submission

- Thorough peer review

- No space constraints or color figure charges

- Immediate publication on acceptance

- Inclusion in PubMed, CAS, Scopus and Google Scholar

- Research which is freely available for redistribution

Submit your manuscript at www.biomedcentral.com/submit 